\title{
SURFACTANT AND ITS ROLE IN THE UPPER RESPIRATORY SYSTEM AND EUSTACHIAN TUBE
}

\author{
Uhliarova B. ${ }^{1,2}$, Svec M. ${ }^{2}$, Calkovska A. ${ }^{1}$
}

\begin{abstract}
${ }^{1}$ Department of Physiology, Jessenius Faculty of Medicine, Comenius University, Martin and ${ }^{2}$ Department of Otorhinolaryngology, FD Roosevelt Faculty Hospital, Banska Bystrica, Slovakia
\end{abstract}

\begin{abstract}
Surfactant research was originally directed toward lung mechanics, however, with growing information on the biology of the surfactant system it has expanded beyond the borders of basic physiology. The research has become interdisciplinary, not only considering aspects of lungs biology relevant for breathing, but also those aspects relevant for airway defence.

Surfactant consists mainly of phospholipids that lower the alveolar surface tension to prevent lung collapse at expiration. They also support mechanical elimination of inhaled pathogens by reducing the viscosity of airway mucus. Approximately $8-10 \%$ of surfactant is made up of proteins. Among them, specific proteins SPA and SP-D play a crucial role in the innate defence system. They belong to collectins family and serve as the first step in immune response to inhaled pathogens. In limited extent, SP-B and SP-C are also involved in immunomodulation.

Although numerous studies have focused on the physiological function of surfactant in the lower airways, relatively little is known about its role in the upper respiratory system. Identification of lamellar bodies in ciliated epithelium of the upper airways indicates that surfactant may have a role in normal sinonasal function and pathology. Decreased levels of the main component of surfactant, phospholipids, have been implicated in atrophic rhinitis and altered levels of surfactant proteins have been observed in a number of respiratory tract diseases. The pattern of inflammation in the upper respiratory tract generally appears to parallel that in the lower airways and nowadays upper respiratory disease and lower airway disease are considered as two manifestations of one pathological process. Therefore, surfactant proteins may play a significant role in the upper respiratory tract diseases.

In addition, surfactant has been identified in the Eustachian tube where it helps to lower the opening pressure between nasopharynx and middle ear. The alterations in surfactant levels may adversely affect Eustachian tube function and contribute to chronic ear infection.

The review summarizes the current knowledge on the presence and the role of surfactant in the upper respiratory system and Eustachian tube.
\end{abstract}

Key words: surfactant, specific proteins, upper airways, otitis media, Eustachian tube

\section{INTRODUCTION}

Pulmonary surfactant, a complex of lipids and proteins lining the alveolar surface, has two crucial roles in respiratory function. It reduces surface tension at the air liquid interphase, facilitating gas exchange and alveolar stability during breathing and interacts with the airway defence system (1).

In addition to the lung, surfactant-like material has been identified in many other human tissues. Lamellar bodies or phospholipids and surfactant proteins have been detected in non-pulmonary sites including upper respiratory tract, Eustachian tube, middle ear, gastrointestinal tract, salivary glands, brain, trachea, lacrimal glands, heart, kidney, pancreas, and male and female urogenital tract (2-7).

\section{Composition of surfactant}

Surfactant is composed of $85-90 \%$ lipids, about $10 \%$ proteins and $2 \%$ carbohydrates. The principal lipid constituents of surfactant are phospholipids. Phosphatidylcholine

Address for correspondence:

Barbora Uhliarova, MD, Department of Physiology, Jessenius Faculty of Medicine, Comenius University, Mala Hora 4, 03601 Martin, Slovak Republic

Phone: +421-43-2633404; e-mail: b.uhliarova@gmail.com 
(PC) species comprise about $75 \%$ of surfactant phospholipids. Nearly half of the PC content is dipalmitoylphosphatidylcholine (DPPC), which is the major component of surfactant and also principal surface tension reducing compound. Up to half of the intra-alveolar content of DPPC is present in the monolayer at the air-liquid interphase. Other phospholipids include phosphatidylglycerol $(\sim 12 \%)$, phosphatidylethanolamine ( 5\%), phosphatidylinositol ( 4\%), phosphatidylserine $(\sim 1.5 \%)$, sphingomyelin $(\sim 1 \%)$, and lysophospholipid $(<1 \%)$. Cholesterol is major neutral lipid, and constitutes about $6-8 \%$ of the total lipids (8).

Optimal surfactant function requires the presence of four specific proteins known as SPA, SP-B, SP-C and SP-D. Hydrophobic surfactant proteins SP-B and SP-C facilitate the adsorption of phospholipids at the air-liquid interphase, where they reduce surface tension. Hydrophillic SP-A and SP-D play a role in the pulmonary host-defence system (9).

\section{Metabolism of surfactant}

Both surfactant lipids and proteins are produced in the alveolar type II cells. The phospholipids and three of four surfactant specific proteins, except SP-C, are also synthesized in the airways in non-ciliated epithelial Clara cells. Surfactant components were also found in secretory cells of airway submucosal glands (10).

Inside the cells, the surfactant components are stored in dense, multilayered membrane structures - the lamellar bodies. Lamellar bodies are excreted into the alveoli and converted into a lattice-like structure of tubular lipid double-layers, called tubular myelin, from which the monolayer at the air-liquid interphase is formed. Formation of these structures and their transformation is facilitated by surfactant proteins (10).

A major clearance pathway for surfactant is an uptake and reutilization by the type II cells. A significant fraction of surfactant is degraded by alveolar macrophages, with minor amounts moving up to the airways and across the epithelial-endothelial barrier into the blood stream (11).

\section{The immunological role of surfactant}

The main function of the phospholipids, primarily DPPC, is to lower the surface tension at the air-liquid interphase, however, they also possess immunomodulating properties. Surfactant lipids have been shown to suppress the release of inflammatory cytokines and prostanoids by monocytes and to inhibit activation of both T and B lymphocytes. They are able to quench surface free radical activity of mineral dust particles and reduce their toxicity in vitro (12). Moreover, the surfactant phospholipids coat the gel layer to reduce the surface tension, decrease mucus viscosity and enhance the elimination of inhaled pathogens (13).

The hydrophobic proteins $\mathbf{S P}-\boldsymbol{B}$ and $\boldsymbol{S} \boldsymbol{P}-\boldsymbol{C}$ have been characterized extensively for their ability to affect lamellar body formation, secretion and creation of the surfactant monolayer that is critical to the lowering surface tension at the air-liquid interphase. Their role is crucial as children born with inherited SP-B and/or SP-C deficiency usually develop acute respiratory failure non-responding to exogenous surfactant replacement (14).

Increasing evidence indicates that SP-B and SP-C are also involved in immunomodulation that is critical for the host defence of the airways. For example, SP-B reduces inflammatory response in the lungs to bacterial lipopolysaccharide (15). In transgenic mice reduction in SP-B expression and the associated abnormalities in reducing surface tension evoked an inflammatory response in alveolar macrophages and alveolar type II cells (16). SP-C-deficient mice are susceptible to bacterial and viral infections and they suffer from excessive inflammation (17). Moreover, surfactant in combination with hydrophobic SP-B and SP-C possesses viscoelastic and rheologic properties that enhance mucociliary clearance (18). It accelerates ciliary beat frequency, decreases mucus viscosity and improves particle clearance from the lungs (19). 
SP-A and SP-D are members of collectins family that belong to C-type lectins named for their aminoterminal collagen-like region and carboxyterminal or carbohydrate recognition domain (CRD). The collectins participate in innate immunity in the period before induction of an antibody-mediated response. These proteins selectively recognize and bind via their CRD to carbohydrate, but also lipopolysaccharide and protein moieties on the surface of bacteria, fungi, viruses and allergens. This binding is followed by interactions with dendritic cells or macrophages and leads to opsonization and pathogen clearance, complement activation, and modulation of leukocyte function including chemotaxis and subsequent cytokine and/or chemokine responses $(20,21)$.

Taken together, SP-A and SP-D are critical in the initial interaction, recognition, processing and subsequent adaptive immune response for a wide number of inhaled pathogens. In addition, SP-A and SP-D promote apoptotic cell uptake by innate immune cells and regulate cytokine and free radical production (9).

Several studies have shown that SP-A and SP-D bind to and inactivate wide range of pathogens, such as Staphylococcus aureus, Haemophilus influenzae type A, Pseudomonas aeruginosa, Streptococcus pneumoniae and a group A streptococci, Klebsiella pneumoniae, Aspergillus, Salmonella minnesota, E. coli, herpers simplex virus, infuenza virus, $M$. tuberculosis, Pneumocystis carinii, Mycoplasma pneumoniae $(22,23)$.

Beside binding to pathogens and affecting antigen processing, SP-A and SP-D affect immunoglobulin $\mathrm{E}$ binding to the allergen and cause a shift in the polarization of $\mathrm{T}$ lymphocytes subpopulations Th1 and Th2 (13). In addition, topical application of SP-A and SP-D have been shown to decrease immunoglobulin $\mathrm{E}$ levels and reduce eosinophilia in mouse model of allergic bronchopulmonary aspergillosis and to cause a marked shift from a pathogenic Th2 profile to a protective Th1 cytokine pattern (22).

While SP-D not being associated with surfactant lipids is solely included in immune processes, surfactant protein A cooperates with SP-B in formation of the tubular myelin and the surface film (24). It does not have an essential role in reduction of surface tension, since mice deficient in SP-A will survive and have normal compliance and lung volumes (25). Moreover, SP-A increases resistance of surfactant to some inhibitors (26).

\section{SURFACTANT IN THE UPPER RESPIRATORY SYSTEM}

The nose and sinuses play an important role in the first line-defence of the respiratory tract. By warming up, humidifying and filtering incoming air the nose and sinuses are essential in the protection and homeostasis of lower airways (27). As in lower airways, surfactant in upper respiratory system may also be impaired by inhaled noxious agents (28).

Despite their differences, both the upper and the lower airways are crucial in the body's defences against inhaled pathogens, and the pattern of inflammation in the upper respiratory tract generally appear to parallel that in the lower airways (29). Recently, the concept of "united airway disease " or "one linked airway disease" has been proposed (30). In this concept, upper airway disease and lower airway disease are considered as two manifestations of one pathological process.

The close relationship between asthma, allergic and nonallergic rhinosinusitis and nasal polyps has been acknowledged for many years. It has been estimated that approximately $90 \%$ of allergic asthmatics suffer from rhinitis, and around $30 \%$ of rhinitis patients suffer from asthma (31). Individuals with asthma sensitive to the ingestion of aspirin may suffer from nasal polyps as part of the disease process (32). Allergic fungal rhinosinusitis is considered to be the upper airway correlate to allergic bronchopulmonary aspergillosis (33). Patients with cystic fibrosis invariably develop chron- 
ic rhinosinusitis (CRS) in addition to their pulmonary disease. This is through the similar mechanism of inspissated mucus, impaired mucociliary clearance, and persistent bacterial infections and inflammation (34). Several studies report the prevalence of chronic nasal symptoms in patients with chronic obstructive pulmonary disease as $40-70 \%(35)$. On the other hand, there is $40 \%$ prevalence of lower airway disease in patients with CRS (36) and, interestingly, 70\% of those patients were first diagnosed as having lower airway disease. Thus, the lungs and the paranasal sinuses share contact with inhaled pathogens and include many of the same morphological and functional properties.

\section{Surfactant phospholipids in the upper airways}

Although numerous studies have focused on the nature and defensive role of surfactant in the lower airways, relatively little is known about its role in the upper respiratory system.

Identification of lamellar bodies in ciliated pseudostratified epithelium of the upper airways $(5,6)$ indicates that surfactant may have a role in normal sinonasal function and pathology. These lipid storage and secretory organelles possibly undergo exocytosis and organize to form surfactant in the lumen of the sinonasal cavity in a fashion similar to that in the lower airways. Biochemical analysis of the nasal aspirate in healthy individuals revealed the presence of phospholipids constituting surfactant as phosphatidylcholine, phosphatidylethanolamine, sphingomyelin and other phospholipids (37). It was observed that phosphatidylcholine constituted $\sim 75 \%$ phospholipids of the nasal aspirate, while phosphatidyethanolamine constituted $\sim 15 \%$, sphingomyelin $\sim 5 \%$ and other phospholipids $4 \%$ (Fig.1).

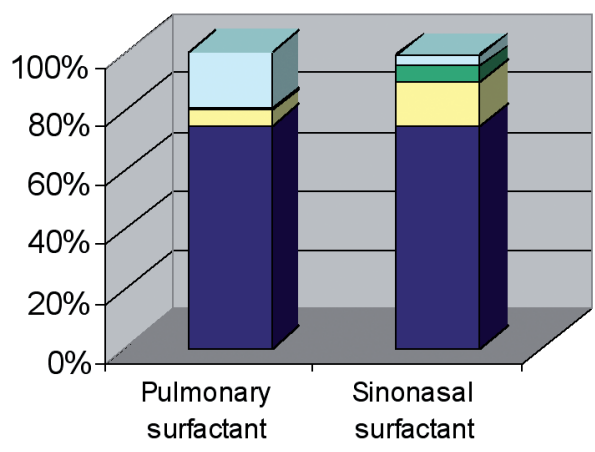

$\square$ Other phospholipids

$\square$ Sphingomyelin

$\square$ Phosphatidy lethanolamine

— Phosphatidylcholine

Fig 1. Differences in phospholipid content of pulmonary and sinonasal surfactants

This phospholipids profile corresponds with that observed in the lung wash (38) and in the Eustachian tube and nose (39) in healthy humans.

In patients with primary atrophic rhinitis compared to the healthy people total phospholipids content decreases and its profile changes (37). The changes are characterized by significant decrease in phosphatidylcholine and increase in phosphatidylethanolamine and sphingomyelin. This is in agreement with the study done by Gunther et al. (40) who demonstrated reduced phospholipids concentrations in the bronchoalveolar lavage fluid in all patients with inflammatory lung injury. The compositional changes in the phospholipids profile are similar to that observed in premature infants with neonatal respiratory distress syndrome and in acute pulmonary inflammation in adult respiratory distress syndrome and/or pneumonia $(40,41)$. 


\section{Surfactant proteins in the upper airways}

Recent studies identified surfactant proteins and their messenger RNA (mRNA) in normal and diseased sinonasal tissue $(42,43)$. Immunolocalization of surfactant specific proteins demonstrates their presence in pseudostratified ciliated epithelium and submucosal secretory ducts of sinonasal mucosa $(44,45)$.

The location of SP-A and D is consistent with the role of these proteins in the innate defence against pathogens at sites of potential invasion of microorganisms. The discovery of surfactant production and secretion by sinonasal mucosa indicates that initial contact and interaction between pathogens and surfactant proteins occurs relatively early after inhalation and deposition into the mucus of the upper respiratory tract.

In sinus mucosal biopsies from patients with cystic fibrosis hydrophillic SP-A and SPD (42), as well SP-B mRNA (46), were up-regulated when compared with healthy controls. The upregulation is likely due to the substantial bacterial infections that accompany this form of chronic rhinosinusitis (CRS), although undetermined genetic factors and immunologic dysfunction could also play a role. Pseudomonas aerigunosa invariably colonizes and infects the sinuses of patients with $\mathrm{CF}$ and has been shown to degrade surfactant components including surfactant proteins (47). This may result in a compensatory response at the cellular level to increase expression of SP mRNA and surfactant production. However, content of SP-A and D in bronchoalveolar lavage fluid was reduced in $\mathrm{CF}$ patients and it was even lower during an active infection (48). In these studies, protein levels only and not the cellular mRNA were measured. It is possible, that in CF patients there is an upregulation of SP-A and D gene expression and subsequent protein production, but these are rapidly degraded in the presence of bacteria.

Lee et al. (49) demonstrated upregulation of SP-A mRNA and more intense expression of SP-A protein in paranasal sinus mucosa of patients with chronic rhinosinusitis than in healthy control. It indicates that the SP-A gene in paranasal sinus mucosa is not only constitutively expressed, but it is also upregulated during inflammation. The upregulation of SP-A mRNA and SP-A protein in the paranasal sinus mucosa in patients with CRS suggests its role in the local defence mechanism of the paranasal sinus mucosa. These findings are similar to that in patients with chronic allergic rhinosinusitis (50). Moreover, the degree of SP-A mRNA expression correlated with severity of disease measured by Rhinitis Symptom Utility Index in patients with allergic rhinitis symptoms. Linking SP-A expression to the severity of nasal symptoms, sneezing and running nose suggests that SP-A may be an important molecule in local nasal inflammation as well, but additional work is necessary to determine whether SP-A elevation is a reaction to local allergy or a mediator of it. In addition, the expression of SPA and SP-D is positively influenced by the degree of cell differentiation into mucociliary epithelium (45).

\section{EFFECT OF SURFACTANT ON EUSTACHIAN TUBE}

Eustachian tube (ET) connects the middle ear with the nasal cavity and it is important for ventilation, protection and clearance of the middle ear (ME). The structure of the ET is similar to other respiratory airways in which the lumen of the tube is bound by a thin fluid layer at the mucosal surface and is surrounded by cartilaginous and muscular elements. Under physiological conditions ET exists in a "collapsed" configuration that protects the middle ear from nasopharyngeal secretions. However, ET is also responsible for maintaining ambient middle ear pressures and clearing the ME fluid into the nasopharynx. The pressure-regulating and clearance functions require an 
open ET in which the resistance to air and fluid flow is minimal. Opening pressure is assumed to reflect the pressure that is needed to overcome all closing forces, including the solid-to-solid adhesion of the ET walls (luminal forces) and pressure of the cartilage and other surrounding tissues (extraluminal forces). The closing pressure is believed to reflect the extraluminal forces, so it has passive ventilatory function (51). Thus, ET dysfunction and the resulting disease complications can develop when the tube is excessively patent or cannot be readily open.

Reduced tubal patency is regarded as possible factor in the development of middle ear disease. Otitis media $(\mathrm{OM})$ is a common childhood disease that includes inflammation of the middle ear mucosa and an accumulation of fluid within the ME. By age of 3 years, a significant number of children (33\%) experience more than three episodes of OM (52). The persistence of OM often results in hearing loss, with possible effects on language acquisition, speech production, and social and educational development (53). Although bacterial or viral infections and nasal allergies contribute to the onset of OM, the development of persistent $\mathrm{OM}$ is associated with a functional impairment of the Eustachian tube (51).

The role of surfactant in ET function has been questioned for several years. As early as in 1963, Flisberg et al. (54) suggested that the surface activity of the mucous lining of the tubal lumen may be important in tubal opening (Fig.2).
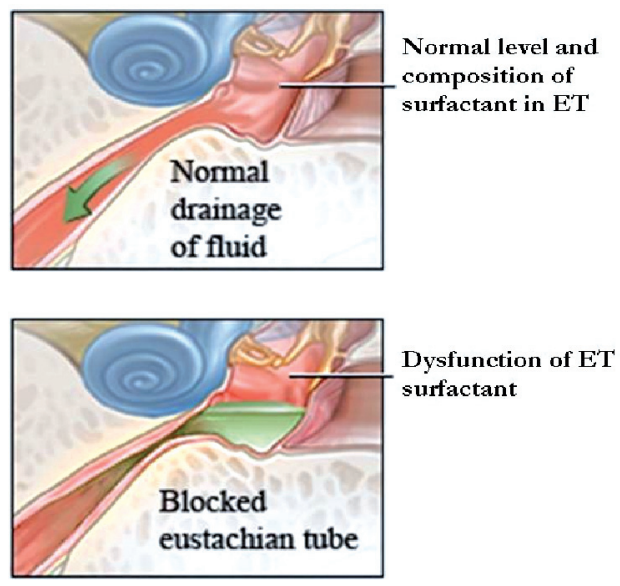

Fig. 2 The role of surface-active material in Eustachian tube (modified according to http://ptolentinobioresearch.wikispaces.com). ET - Eustachian tube

Since then, surface tension-lowering factors (surfactants) have been identified in both the middle ear and ET, both in animals (55) and humans (56). Surfactant-producing cells morphologically similar to the alveolar type II cells in the lungs were found in the dorsal part of the ET (57).

ET surfactant is composed of specific surfactant proteins (58) and a mixture of predominantly phospholipids, especially phosphatidylcholines and sphingomyelins (59). Phospholipids are known to reduce the surface tension at an air-aqueous interphase. However, because the ET is normally closed, the ET surfactant covering the epithelium is supposed to act as a release agent by preventing solid-to-solid adhesion (59). Grace et al. (56) compared the phospholipids content of middle ear effusions resulting from ET obstruction in adult patients with that of children with secretoric otitis media. In both groups, surface tension-lowering substances were isolated but the composition 
was different from adults having a higher amount of sphingomyelin. In other study, a higher sphingomyelin/phosphatidylcholine ratio was present in children with secretoric otitis media than in those without OM (60) indicating a lower degree of surfacelowering properties.

Several recent studies have investigated the effect of exogenous surfactant on ET mechanics. Exogenous surfactant reduces opening pressure of the ET (61), also under pathological conditions in patients with otitis media $(62,63)$. It also seems to improve clearance function of the ET as a significant enhancement of mucociliary transport has been observed after the application of surfactant, both in vitro and in vivo (64). Theoretically, enrichment of administered surfactant by substances increasing its resistance (65) or having antimicrobial effect (66) could improve efficacy of such therapy.

Thus, the presence of a sufficient quantity and quality of ET surfactant may be an important determinant of ET functions and mechanics. Dysfunction of ET surfactant could be a possible factor in the development of serous otitis media.

\section{CONCLUSION}

Although numerous studies have focused on the nature and defensive role of surfactant in the lower airways, relatively little is known about its role in the upper respiratory system.

The lamellar body arrangement of phospholipids has now been demonstrated in the both normal and diseased sinus tissue, resulting in the implication that these structures may play a crucial role in the regulation of mucus viscosity and in mucociliary clearance against inhaled pathogens as well. Decreased levels of phospholipids have been found in atrophic rhinitis. Surfactant proteins make up a relatively small portion of surfactant, but appear to have an important role especially in innate immunity. They are crucial in the initial interaction, recognition, processing, and subsequent adaptive immune responses for a wide variety of inhaled pathogens and allergens. Presence of surfactant proteins in a variety of normal and diseased sinonasal tissue indicates that these proteins may play a significant role in physiology and pathophysiology of sinonasal diseases. Understanding the role of surfactant proteins in diseased and healthy states may help to develop novel treatments for sinonasal pathologies.

In addition, surfactant has been identified in the Eustachian tube where it helps to lower the opening pressure between the nasopharynx and middle ear. Therefore, alteration in surfactant levels may adversely affect Eustachian tube function and contribute to chronic ear infection.

\section{REFERENCES}

1. Halliday HL. Surfactants: Past, present and future. J Perinatol 2008; 28 (Suppl 1): S47-56.

2. Madsen J, Tornoe I, Nielsen O, Koch C, Steinhilber W, Holmskov U. Expression and localization of lung surfactant protein A in human tissues. Am J Respir Cell Mol Biol 2003; 29(5): 591-597.

3. Lin Z, deMello D, Phelps DS, Koltun WA, Page M, Floros J. Both human SP-A1 and SP-A2 genes are expressed in small and large intestine. Pediatr Pathol Mol Med 2001; 20(5): 367-386.

4. Madsen J, Klien A, Torneo I, Skjodt K, Koch C, Holmskov U. Localization of surfactant protein D on mucosal surfaces in human tissues. J Immunol 2000; 164 (11): 5866-5870.

5. Woodwort BA, Smythe N, Spicer SS, Schulte BA, Schlosser RJ. Presence of surfactant lamellar bodies in normal and diseased sinus mucosa. ORL J Otorhinolaryngol Relat Spec 2005; 67(4): 199-202.

6. Svane-Knudsen V, Rasmussen G, Clausen PP. Surfactant-like lamellar bodies in the mucosa of the human nose. Acta Otolaryngol 1990; 109(3-4): 307-313.

7. Dutton JM, Goss K, Khubchandani KR, Shah ChD, Smith RJH, Snyder JM. Surfactant protein A in rabbit sinus and middle ear mucosa. Ann Otol Rhinol Laryngol 1999; 108(10): 915-924. 
8. Wright JR, Clemets JA. Metabolism and turnover of lung surfactant. Am Rev Respir Dis 1987; 136(2): 426-444.

9. Pastva AM, Wright JR, Williams KL. Immunomodulatory roles of surfactant proteins A and D. Implication in lung disease. Proc Am Thorac Soc 2007; 4(3): 252-257.

10. Johansson J, Curstedt T, Robertson B. The proteins of the surfactant system. Eur Respir J 1994; 7(2): 372-391.

11. Wright JR, Dobbs LG. Regulation of pulmonary surfactant secretion and clearance. Annu Rev Physiol 1991; 53: 395-414.

12. Gehr P, Green FHY, Geiser M, Hof V, Lee MM, Schurch S. Airway surfactant, a primary defense barrier: Mechanical and immunological aspects. J Aerosol Med 1996; 9(2): 163-181.

13. Schlosser RJ. Surfactant and its role in chronic sinusitis. Ann Otol Rhinol Laryngol 2006, 196: 40-44.

14. Nogee LM, Garnier G, Dietz HC, Singer L, Murphy AM, deMello DE, Colten HR. A mutation in the surfactant protein B gene responsible for fatal neonatal respiratory disease in multiple kinders. J Clin Invest 1994; 93(4): 1860-1863.

15. Miles PR, Bowman L, Rao KM, Baatz JE, Huffman L. Pulmonary surfactant inhibits LPS-induced nitric oxide production by alveolar macrophages. Am J Physiol 1999; 276(1): L186-196.

16. Ikegami M, Whitsett JA, Martis PC, Weaver TE. Reversibility of lung inflammation caused by SP-B deficiency. Am J Physiol Lung Cell Mol Physiol 2005; 289(6): L962-970.

17. Glasser SW, Senft AP, Whitsett JA, Maxfield MD, Ross GF, Richardson TR, Prows DR, Xu Y, Korfhagen TR. Macrophage dysfunction and susceptibility to pulmonary pseudomonas aeruginosa infection in surfactant protein c-deficient mice. J Immunol 2008; 181(1): 621-628.

18. De Sanctis GT, Tomkiewicz RP, Rubin BK, Schurch S, King M. Exogenous surfactant enhances mucociliary clearance in the anesthetized dog. Eur Respir J 1994; 7(9): 1616-1621.

19. Kakuta Y, Sasaki H, Takishima T. Effect of artificial surfactant on ciliary beat frequency in guinea pig trachea. Respir Physiol 1991; 83(3): 313-321.

20. Chroneos ZC, Sever-Chroneos Z, Shepherd VL. Pulmonary surfactant: An immunological perspective. Cell Physiol Biochem 2010; 25(1): 13-26.

21. Wright JR. Immunoregulatory functions of surfactant proteins. Nat Rev Immunol 2005; 5(1): 58-68.

22. Kishor U, Madan T, Sarma PU, Singh M, Urban BC, Reid KB. Protective roles of pulmonary surfactant proteins, SP-A and SP-D, against lung allergy and infection caused by Aspergillus fumigatus. Immunobiology 2002; 205(4-5): 610-618.

23. Pikaar JC, Voorhout WF, van Golde LM, Verhoef J, Van Strijp JA, van Iwaarden JF. Opsonic activities of surfactant proteins A and D in phagocytosis of gram negative bacteria by alveolar macrophages. $J$ Infect Dis 1995; 172(2): 481-489.

24. Williams MC, Hawgood S, Hamilton RL. Changes in lipid structure produced by surfactant proteins SPA, SP-B and SP-C. Am J Respir Cell Mol Biol 1991; 5(1): 41-50.

25. Korfhagen TR, Bruno MD, Ross GF, Huelsman KM, Ikegami M, Jobe AH, Wert SE, Stripp BR, Morris RB, Glasser SW, Bachurski CJ, Iwamoto HS, Whitsett JA. Altered surfactant function and structure in SP-A gene targeted mice. Proc Natl Acad Sci USA 1996; 93(18): 9594-9599.

26. Sun B, Curstedt T, Lindgren G, Franzén B, Alaiya AA, Calkovska A, Robertson B. Biophysical and physiological properties of a modified porcine surfactant enriched with surfactant protein A. Eur Respir J 1997; 10(9): 1967-1974.

27. Hens G, Hellings PW. The nose: gatekeeper and trigger of bronchial disease. Rhinology 2006; 44(3): 179-187.

28. Calkovska A, Engler I, Mokra D, Drgova A, Kmetova M, Tatarkova Z, Calkovsky V, Brozmanova M, Tatar M. Differences in oxidative status, lung function, and pulmonary surfactant during long-term inhalation of medical oxygen and partially ionized oxygen in guinea pigs. J Physiol Pharmacol 2008; 59 (Suppl. 6): 173-181.

29. Calkovsky V, Hajtman A. Functional aspects of upper and lower airways. Head and Neck Diseases 2003; 12(3/4): 23-27 (in Slovak).

30. Passalacqua G, Ciprandi G, Canonica GW. The nose-lung interaction in allergic rhinitis and asthma: united airways disease. Curr Opin Allergy Clin Immunol 2001; 1(1): 7-13.

31. Bachert C, Patou J, Van Cauwenberge P. The role of sinus disease in asthma. Curr Opin Allergy Clin Immunol 2006; 6(1): 29-36.

32. Farooque SP, Lee TH. Aspirin-sensitive respiratory disease. Annu Rev Physiol 2009; 71(1): 465-487.

33. Pakdaman MN, Corry DB, Luong A. Fungi linking the pathophysiology of chronic rhinosinusitis with nasal polyps and allergic asthma. Immunol Invest 2011; 40(7): 767-785.

34. Boari L, de Castro Júnior NP. Diagnosis of chronic rhinosinusitis in patients with cystic fibrosis: correlation between anamnesis, nasal endoscopy and computed tomography. Braz J Otorhinolaryngol 2005; 71(6): 705-710.

35. Roberts NJ, Llyod-Owen SJ, Rapado F, Patel IS, Wilkinson TM, Donaldson GC, Wedzicha JA. Relationship between chronic nasal and respiratory symptoms in patients with COPD. Respir Med 2003; 97(8): 909914.

36. Kim HY, So YK, Dhong HJ, Chung SK, Choi DCh, Kwon NH, Oh MJ. Prevalence of lower airway diseases in patients with chronic rhinosinusitis. Acta Oto-Laryngologica 2007; 127(Suppl. 558): 110-114. 
37. Sayed RH, Abou-Elhamd KE, Abdel-Kader M, Saleem TH. Study of surfactant level in cases of primary atrophic rhinits. J Laryngol Otol 2000; 114(4): 254-259.

38. King RJ, Clements JA. Surface active materials from dog lung. II. Composition and physiological correlation. Am J Physiol 1972; 223(3): 715-726.

39. Hills BA. Analysis of eustachian surfactant and its function as a release agent. Arch Otolaryngol 1984; 110(1): 3-9.

40. Günther A, Siebert C, Schmidt R, Ziegler S, Grimminger F, Yabut M, Temmesfeld B, Walmrath D, Morr $\mathrm{H}$, Seeger W. Surfactant alterations in severe pneumonia, acute respiratory distress syndrome and cardiogenic lung oedema. Am J Respir Crit Care Med 1996; 153(1): 176-184.

41. Gregory TJ, Longmore WJ, Moxley MA, Whitsett JA, Reed CR, Fowler AA 3rd, Hudson LD, Maunder RJ, Crim C, Hyers TM. Surfactant chemical composition and biophysical activity in acute respiratory distress syndrome. J Clin Invest 1991; 88(6): 1976-1981.

42. Woodworth BA, Wood R, Baatz JE, Schlosser RJ. Sinonasal surfactant protein A1, A2, and D gene expression in cystic fibrosis: A preliminary report. Otolaryngol Head Neck Surg 2007; 137(1): 34-38.

43. Woodworth BA, Neal JG, Newton D, Joseph K, Kaplan AP, Baatz JE, Schlosser RJ. Surfactant protein A and D in human sinus mucosa: a preliminary report. ORL J Otorhinolaryngol Relat Spec 2007; 69(1): 57-60.

44. Woodworth BA, Lathers D, Neal JG, Skinner M, Richardson M, Young MR, Schlosser RJ. Immunolocalization of surfactant protein A and D in sinonasal mucosa. Am J Rhinol 2006, 20(2): 461465.

45. Kim JK, Kim SS, Rha KW, Kim ChH, Cho JH, Lee ChH, Lee JG, Yoon JH. Expression and localization of surfactant proteins in human nasal epithelium. Am J Physiol Lung Cell Mol Physiol 2007; 292(4): L879L884.

46. Woodworth BA, Wood R, Bhargave G, Cohen NA, Baatz JE, Schlosser RJ. Surfactant protein B detection and gene expression in chronic rhinosinusitis. Laryngoscope 2007; 117(7): 1296-1301.

47. Beatty AL, Malloy JL, Wright JR. Pseudomonas aeruginosa degrades pulmonary surfactant and increases conversion in vitro. Am J Respir Cell Mol Biol 2005; 32(2): 128-134.

48. Noah TL, Murphy PC, Alink JJ, Leigh MW, Hull WM, Stahlman MT, Whitsett JA. Bronchoalveolar lavage fluid surfactant protein A and surfactant protein D are inversely related to inflammation in early cystic fibrosis. Am J Respir Crit Care Med 2003; 168(6): 685-691.

49. Lee HM, Kang J, Woo JS, Chae SW, Lee SH, Hwang SJ. Upregulation of surfactant protein A in chronic rhinosinusitis. Laryngoscope 2006; 116(2): 328-330.

50. Wooten CT, Labadie RF, Chen A, Lane KF. Differential expression of surfactant protein A in the nasal mucosa of patients with allergy symptoms. Arch Otolaryngol Head Neck Surg 2006; 132(9): 1001-1007.

51. Bluestone CD, Klein JO. Physiology, pathophysiology and pathogenesis. In: Donley SS, editor. Otitis media in infants and children. 3rd ed. Philadelphia, PA: Saunders; 2001, p. 34-57.

52. Teele DW, Klein JO, Rosner B. Epidemiology of otitis media during the first seven years of life in children in greater Boston: a prospective, cohort study. J Infect Dis 1989; 160(1): 83-94.

53. Teele DW, Klein JO, Chase C, Menyuk P, Rosner BA. Otitis media in infancy and intellectual ability, school achievement, speech and language at age of 7 years.Greater Boston Otitis Media Study Group. Pediatr Infect Dis J 1990; 162(3): 685-694.

54. Flisberg K, Ingelstedt S, Ortegren U. On middle ear pressure.Acta Otolaryngol (Stockh) 1963; 182: 43-56.

55. Hagan WE. Surface-tension lowering substance in eustachian tube function. Laryngoscope 1977; 87(7): 1033-1045.

56. Grace A, Kwok P, Hawke M. Surfactant in middle ear effusions. Otolaryngol Head Neck Surg 1984; 96(4): 336-340.

57. Karchev T, Watanabe N, Fujiyoshi T, Mogi G, Kato S. Surfactant-producing epithelium in the dorsal part of the cartilaginous eustachian tube of mice. Light, transmission, and scanning electron microscopic observations. Acta Otolaryngol (Stockh) 1994; 114(1): 64-69.

58. Paananen R, Glumhoff V, Hallman M. Surfactant protein A and D expression in the porcine eustachian tube. FEBS Lett 1999; 452(3): 141-144.

59. Hills BA. Analysis of eustachian surfactant and its function as a release agent. Arch Otolaryngol 1984; 110(1): 3-9.

60. Svane-Knudsen V, Larsen HF, Brask T. Secretory otitis media - A question of surface activity in eustachian tube? Acta Otolaryngol (Stockh) 1988; 105(1-2): 114-119.

61. Heerbeek N, Tonnaer E, Ingels K, Curfs J, Cremers C. Effect of exogenous surfactant on ventilatory and clearance function of rat's eustachian tube. Otol Neurootol 2003; 24(1): 6-10.

62. Calkovsky V, Hajtman A. The importance of surface-active material in Eustachian tube and the relation to otitis media. Otorinol a foniatr 2007; 56(3): 160-163 (in Slovak).

63. Koten M, Uzun C, Yazig R, Adali MK, Karasalihoglu AR, Tatman-Otkun M, Altaner S. Nebulized surfactant as a treatment choice for otitis media with effusion: an experimental study in the rabbit. $J$ Laryngol Otol 2001; 115(5): 363-368.

64. De Sanctis GT, Tomkiewicz RP, Rubin BK, Schück S, King M. Exogenous surfactant enhances mucociliary clearance in the anesthetized dog. Eur Respir J 1994; 7(9): 1616-1621. 
65. Calkovska A, Some M, Linderholm B, Curstedt T, Robertson B. Therapeutic effects of exogenous surfactant enriched with dextran in newborn rabbits with respiratory failure induced by airway instillation of albumin. Pulm Pharmacol Ther 2008; 21(2): 393-400.

66. Calkovska A, Some M, Linderholm B, Johansson J, Curstedt T, Robertson B. Biophysical and physiological properties of porcine surfactant enriched with polymyxin B. Biol Neonate 2005; 88( 2): 101-108.

Acknowledgement: The work was supported by Grant of Ministry of Education VEGA No. 1/0416/12 and by Centre of Experimental and Clinical Respirology No. 26220120034, co-financed from EU sources.

Received: February, 10, 2012

Accepted: March, 11, 2012 